\title{
GAMBARAN ANEMIA PADA IBU HAMIL DI WILAYAH KERJA PUSKESMAS KALASAN
}

\author{
"Sri Wahtini, Evi Wahyuntari \\ Kebidanan, Universitas ‘Aisyiyah Yogyakarta, *email: wahtini123@gmail.com
}

INFO ARTIKEL
Riwayat Artikel:
Diterima: 11-09-2019
Disetujui: 25-11-2019

Kata Kunci:

Anemia

Hamil

Karakteristik Ibu

\begin{abstract}
ABSTRAK
Abstrak: Prevalensi anemia di Negara berkembang 37,1\%-75\%. Anemia merupakan faktor penting dalam kehamilan karena berhubungan dengan kejadian morbiditas ataupun mortalitas pada ibu dan janin. Tujuan penelitian adalah untuk mengetahui karakteristik ibu hamil dengan anemia. Penelitian deskriptif. Populasi dalam penelitian ibu hamil dengan anemia di wilayah kerja Puskesmas Kalasan. Sampel 58 ibu hamil dengan kriteria inklusi inklusi ibu hamil anemia, tidak ada penyakit penyerta. Kriteria eksklusi: tidak mau menjadi responden. Pengumpulan data menggunakan kuesioner data sosio demografi (umur, pendidikan, pekerjaan, data obstetrik (paritas, riwayat anemia). Hasil: gambaran ibu hamil dengan anemia 49 (84,5\%) responden rentang usia tidak berisiko, 51 (88\%) dengan pendidikan tinggi, 35 (60\%) responden dengan paritas multigravida, 54 (93\%) tidak memiliki riwayat anemia sebelumnya.
\end{abstract}

\begin{abstract}
Anemia is an important factor in pregnancy because it is associated with the incidence of morbidity or mortality in the mother and fetus. The purpose of this study is to determine the characteristics of pregnant women with anemia. Descriptive research. Population in the study was pregnant women with anemia in the working area of the Kalasan Community Health Center. Sample 58 pregnant women with inclusion criteria anemia in pregnant women, there were no accompanying diseases. Exclusion criteria: do not want to be a respondent. Data collection using socio demographic data questionnaires (age, education, occupation, obstetric data (parity, history of anemia). Results: description of pregnant women with anemia 49 (84.5\%) respondents at no risk age range, 51 (88\%) with higher education, 35 (60\%) respondents with multigravida parity, 54 (93\%) had no history of previous anemia.
\end{abstract}

\section{A. LATAR BELAKANG}

Kehamilan merupakan proses fisiologis dimana pada masa kehamilan terjadi perubahan baik fisik maupun psikologis. Perubahan fisik yang sering terjadi salah satunya adalah perubahan pada sirkulasi darah yang dapat menyebabkan hemodilusi. Anemia pada kehamilan merupakan salah satu kelainan dalam kehamilan terutama di negara berkembang. World Health Organization (WHO) memperkirakan lebih dari 30\% wanita hamil mengalami anemia dan penyebabnya karena anemia defisiensi besi atau defisiensi asam folat (1).

Klasifikasi anemia menurut WHO (2) adalah ringan (10-11,9gr\%), sedang (7-9,9gr\%o dan berat ( $<7$ gr\%). Secara fisiologis anemia pada ibu hamil adalah karena terjadinya perubahan volume plasma dimulai pada 6 minggu kehamilan, dimana sel darah merah tidak bertambah, sehingga menyumbang penurunan fisologis konsentrasi $\mathrm{Hb}(3)$.

Prevalensi anemia di setiap Negara berbeda dengan kisaran 41,8\%. Di Amerika prevalensi mulai terendah 5,5\% sedangkan di Gambia prevalensi tertinggi mencapai $75 \%$ (4). Prevalensi anemia di Indonesia 37,1\% (5). Kejadian anemia bisa terjadi sebelum hamil atau terjadi saat kehamilan. Anemia dalam kehamilan disebabkan karena defisiensi besi dan berhubungan dengan pola nutrisi yang rendah akan zat besi (6).

Anemia merupakan faktor penting dalam kehamilan karena berhubungan dengan kejadian morbiditas ataupun mortalitas pada ibu dan janin. Faktor risiko anemia antara lain umur, riwayat anemia pada kehamilan sebelumnya, sosial ekonomi (6) (7). Penelitian Abhriha et al (2014) didapatkan paritas, frekuensi makan dan konsumsi daging kurang dari 1 kali/ minggu merupakan faktor risiko anemia (8).

Dampak dari anemia antara lain persalinan prematur, bayi berat lahir rendah, sedangkan pada ibu anemia akan berdampak pada 20-40\% terhadap kejadian kematian ibu seperti kegagalan jantung, pre eklamsia, perdarahan postpartum dan infeksi postpartum (7). Penelitan Abuaouf (2015) di dapatkan bahwa anemia berdampak terhadap ibu dan janin. Pada Janin akan menyebabkan risiko infeksi perinatal, perkembangan janin terhambat/IUGR, BBLR. Sedangkan dampak anemia pada ibu antara lain preeklamsia, perdarahan (9).

Sosial ekonomi merupakan salah satu faktor yang berpengaruh terhadap kejadian anemia pada ibu. Kondisi sosial ekonomi memiliki kaitan yang erat dengan masalah kesehatan. Kondisi sosial ekonomi yang rendah akan 
berpengaruh terhadap penyediaan kecukupan mineral yang berfek pada kejadian anemia pada ibu.

Program konsumsi tablet tambah darah pada ibu hamil merupakan salah satu program pemerintah untuk memenuhi kecukupan zat besi yang tidak tercukupi dengan kebutuhan makan sehari-hari. Pemerintah Indonesia menganjurkan konsumsi tablet tambah darah pada ibu hamil sebanyak 90 tablet dalam masa kehamilan di lanjutkan selama 42 hari setelah melahirkan (5). Tujuan dari penelitian ini adalah mengetahui gambaran ibu hamil dengan anemia.

\section{B. METODE PENELITIAN}

Penelitian ini menggunakan metode penelitian deskriptif dengan pendekatan kuantitatif. Populasi dalam penelitian ini adalah ibu hamil dengan anemia di wilayah kerja Puskesmas Kalasan. Teknik sampling dengan consequtive sampling. Sampel dalam penelitian ini berjumlah 58 responden dengan kriteria inklusi ibu hamil anemia, tidak ada penyakit penyerta. Kriteria eksklusi: tidak mau menjadi responden. Pengumpulan data menggunakan kuesioner data sosio demografi (umur, pendidikan, pekerjaan, data obstetrik (paritas, riwayat anemia). Responden yang telah diberikan lembar informed consent diminta mengisi data demografi. Analisi data menggunakan analisis bivariate untuk mengetahuai jumlah dan prosentase ibu hamil dengan anemia.

\section{HASIL DAN PEMBAHASAN}

\section{Hasil}

Responden dalam penelitian ini ibu hamil dengan anemia di wilayah kerja Puskesmas Kalasan. Hasil penelitian dapat dilihat di tabel 1.

TABEL 1

Gambaran Anemia pada Ibu Hamil

\begin{tabular}{ccc}
\hline Variabel & Jumlah & Prosentase \\
\hline Umur & & \\
Tidak berisiko & 49 & 84,5 \\
Risiko & 9 & 15,5 \\
Pendidikan & & 88 \\
Tinggi & 51 & 12 \\
Rendah & 7 & \\
Pekerjaan & & 50 \\
Bekerja & 19 & 50 \\
Tidak bekerja & 19 & 40 \\
Paritas & & 60 \\
Primi & 23 & \\
Multi & 35 & 57 \\
Jarak kehamilan & & 42 \\
$\quad>2$ tahun & 33 & \\
$<2$ tahun & 25 & 93 \\
Riwayat anemia & & 7 \\
Tidak & 54 & \\
Ya & 4 & \\
\hline
\end{tabular}

Berdasarkan tabel 1 didapatkan bahwa gambaran ibu hamil dengan anemia 49 (84,5\%) responden rentang usia tidak berisiko, 51 responden (88\%) dengan pendidikan tinggi, 35 (60\%) responden dengan paritas multigravida, 33 (57\%) responden dengan jarak kehamilan > 2 tahun, 54 (93\%) tidak memiliki riwayat anemia sebelumnya.

\section{Pembahasan}

Berdasarkan hasil Abhriha et al didapatkan prevalensi anemia 19,3\% (8). Prevalensi anemia di negara berkembang antara 33-75\% sedangkan di negara maju prevalensi anemia 15\% (10). Perbedaan prevalensi anemia tergantung di setiap negara. Pada prinsipnya ibu hamil membutuhkan $20 \mathrm{mg}$ zat besi setiap harinya. Banyak faktor yang berpengaruh salah satunya adalah jarak kehamilan.

Dalam penelitian ini didapatkan 33 (57\%) responden dengan jarak kehamilan lebih dari 2 tahun. Penelitian sebelumnya didapatkan umur, pendapatan, tidak berhubunagn dengan kejadian anemia (8). Konsumsi buah 2-3 kali seminggu berhungan dengan penurunan kejdian anemia. Kurangnya mikronutrien meningkatkan bioavaibility terhadap zat besi. ANC merupakan salah satu kunci ANC digunakan sebagai pencegahan, diagnose dan terapi dengan komplikais pada wanita hamil. Pemeriksaan kehamilan secara dini dan pemeriksaan secara rutin selam kehamilan memberikan keuntungan pada ibu untuk dapat meningkatkan kesehatan ibu dan janinnya.

\section{a. Umur}

Dalam penelitian ini didapatkan 49 (84,5\%) responden pada renatng usia tidak berisiko yaitu rentang umur 20-35 tahun. Hal ini sesuai dengan penelian yang dilakukan Prakash et al (2015) pada 200 ibu hamil di Nepal didapatkan bahwa umur tidak berhubungan dengan anemia (10) dengan rentang usaia 25-30 tahun. Sedangkan penelitian Dulay et al (2018) didapatkan bahwa umur tidak berhubungan dengan anemia (5) (11). Berbeda dengan penelitian di Arab didapatkan bahwa umur berhubungan dengan anemia pada kehamilan terutama umur dibawah 20 tahun. Umur berhubungan dengan anemia (8). Umur $<20$ tahun merupakan usia berisiko karena pada usia tersebut organ reproduksi belum berfungsi dengan baik, selain itu pada usia tersebut merupakan masa pertumbuhan, sehingga asupan gizi digunakan untuk tumbuh kembangnya.

\section{b. Pendidikan}

Hasil penelitian didapatkan 51 (88\%) responden berpendidikan tinggi. Penelitian yang dilakukan Sharma (2013) dengan responden ibu hamil di India didapatkan bahwa pendidikan berhubungan dengan kejadian anemia (12) (13). Hal ini diperkirakan karena pendidikan berpengaruh terhadap pengetahuan ibu terutama dalam hal menyiapkan makanan yang bernutrisi. Selain itu pendidikan berpengaruh terhadap kesiapan dan pengetahuan dalam menjalani kehamilan dan persalinan. Di Indonesia sendiri didapatkan bahwa pendidikan tidak berhubungan dengan kejadian anemia (5).

Hasil penelitian didapatkan jumlah responden yang bekerja dan yang tidak bekerja jumlahnya sama yaitu 19 (50\%). Penelitian sebelumnya pada 200 ibu hamil di 
Nepal didapatkan bahwa ibu yang tidak bekerja berhubungan dengan anemia (10).

Paritas dalam penelitian ini didapatkan 35 (60\%) responden dengan multipara. Paritas berhubungan dengan anemia. Berdasarkan penelitian Daulay et al (2018) di Sumatra utara didapatkan bahwa paritas berhubungan dengan kejadian anemia, dimana ibu dengan paritas lebih 2 kali mengalami anemia bila di bandingkan dengan paritas kurang dari 2 kali. Hal ini disebakan karean ibu dengan multigravida memiliki cadangan besi yang berkurang karena proses kehamilan sebelumnya dan belum mencukupi bila teejadi kehamilan lagi. Penelitian Punkar et al (2017) gravida dan paritas berhubungan dengan anemia (13). Penelitian Nwizu (2011) didapatkan bahawa primigravida berisko terhadap kejadian anemia (14).

Jarak persalinan penelitian sebelumnya didapatkan bahwa jarak persalinan yang terlalu dekat tidak mendukung ibu untuk mengembalikan cadangan nutrisi untuk melanjutkan proses reproduksi berikutnya. Kondisi ini diperparah dengan ketidaktersediaan diet seimbang (15). Di Nigeria didapatkan bahwa Jarak persalinan yang teralu dekat berhubunagn dengan anemia (14), hal tersebut dikarenakan ibu dengan jarak persalinan yang terlalu dekat tidak memberikan kesempatan kepada ibu untuk mengembalikan fungsi organ reproduksi terhadap kehamilan yang dulu sehingga menimbulkan deplesion sindrom. Ibu dengan anemia di kehamilan sebelumnya membutuhkan waktu kurang lebih 2 tahun untuk pemulihan pengembalian kadar $\mathrm{Hb}$.

Dari penelitian ini didapatkan bahwa 54 (93\%) responden tidak mengalami anemia sebelumnya. Riwayat anemia pada ibu berhubungan dengan luaran kehamilan seperti bayi berat lahir rendah, dan angka kesakitan dan kematian. Bayi yang lahir dari ibu yang anemia cenderung akan mengalamai kekurangan zat besi dan anemia pada awal kehidupan (16), hal ini yang akan berdampak pada perkembangan kognitif dan pertumbuhan fisik bayi (17). Pemberian tablet zat besi secara rutin dapat digunakan untuk mengurangi masalah global kekurangn zat besi dan mencegah efek negative dari anemia. Konsumsi zat besi juga mempunyai efek samping diantaranya mual muntah dan konstipasi. Oleh karenanya pemberian tablet $\mathrm{Fe}$ lebih baik diberikan pada saat mulai konsepsi dan sesegera mungkin selama bisa diberikan. Serta perlu dingat untuk meningkatkan konsumsi mikronutrien seperti zinc, cooper, vitamin A dan E (9).

Anemia banyak terjadi pada ibu hami di TM III hal ini dikarenakan peningkatan volume plasma yang lebih tinggi dibandingkan peningkatan masa eritrosit, dan juga anemia disebakan karena peningkatan kebutuhan oksigen pada bayi yang sedang berkembang. (18)

\section{SIMPULAN DAN SARAN}

\section{Simpulan}

Gambaran anemia di wilayah kerja Puskesmas Kalasan sebagian besar responden tidak mengalami anemia sebelumnya.

\section{Saran}

Dengan mengetahui karakteristik responden, maka kejadian dapat diminimalisir dengan melakukan deteksi dini terhadap faktor risiko.

\section{UCAPAN TERIMA KASIH}

Terimakasih kepada Kementerian Riset dan Teknologi Pendidikan Tinggi yang telah memberikan kesempatan dan pendanaan dalam penelitian ini.

\section{DAFTAR RUJUKAN}

[1] Shiro kozuma. Approaches to Anemia in Pregnancy. JMAJ. 2009;52:214-8.

[2] WHO. Haemoglobin concentrations for the diagnosis of anaemia and assessment of severity. Geneva, Switz World Heal Organ. 2011;1-6.

[3] Sifakis S, Pharmakide G. Anemia in Pregnancy. Ann N Y Acad Sci. 2006;900(1):125-36.

[4] Anlaakuu P, Anto F. Anaemia in pregnancy and associated factors : a cross sectional study of antenatal attendants at the Sunyani Municipal Hospital , Ghana. BioMed Cent. 2017;10:4-11.

[5] Daulay M, Martina SJ, Lestari S, Syarifah S, Keumalasari D, Fujiati II. The prevalence of anemia in pregnant women and its associated risk factors in North Sumatera, Indonesia. IOP Conf Ser Earth Environ Sci. 2018;125:12195.

[6] Hasswane N, Bouziane A, Mrabet M, Laamiri FZ, Aguenaou H, Barkat A. Prevalence and Factors Associated with Anemia Pregnancy in a Group of Moroccan Pregnant Women. J Biosci Med. 2015;3(10):88-97.

[7] Prakash S, Yadv K. Maternal Anemia in Pregnancy: An Overview. Int J Pregnancy Pharm Res. 2015;4(August).

[8] Abriha A, Yesuf ME, Wassie MM. Prevalence and associated factors of anemia among pregnant women of Mekelle town: A cross sectional study. BMC Res Notes. 2014;7(1).

[9] Ouf N, Jan M. The impact of maternal iron deficiency and iron deficiency anemia. Saudi Med Joiurnal. 2015;36(2):146-9.

[10] Satyam Prakash, Khushbu Yadav, Bhuvnesh Bhardwaj, Sangita Chaudhary. Incidence of Anemia and its Sociodemographic determinants among pregnant women attending for antenatal care: A cross sectional study (PDF Download Available). Int J Med Heal Res [Internet]. 2015;(August 2016):12-7. Available from: https://www.researchgate.net/publication/306394937_I ncidence_of_Anemia_and_its_Socio-

demographic_determinants_among_pregnant_women_a ttending_for_antenatal_care_A_cross_sectional_study

[11] Kumari P. Prevalence Of Anemia and Knowledge of Risk Factors About Anemia in Prehnant Women: A Study at Primary Health Cares. J Eur Biomed Pharm Sci. 2018;5(January).

[12] Priyanka Sharma PS. Prevalence of anemia and sociodemographic factors associated with anemia among pregnant women attending antenatal Hospital in Jaipur 
4 Midwifery Journal | Vol. 5, No. 1, Januari 2020, hal 1-4

City, India. IOSR J Pharm Biol Sci. 2013;6(3):1-5.

[13] Pundkar R, Powar J, Sonar S, Desai M. Risk Factors for Anemia in Pregnancy : A Case Control Study. Walawalkar Int Med J. 2017;4(4):17-25.

[14] Nwizu EN, Iliyasu Z, Ibrahim SA, Galadanci HS. Sociodemographic and maternal factors in anaemia in pregnancy at booking in Kano, northern Nigeria. Afr J Reprod Health [Internet]. 2011;15(4):33-41. Available from: http://www.ncbi.nlm.nih.gov/pubmed/22571103

[15] Abdelrahman EG, Gasim G, Musa IR, Elbashir LM, Adam I. Red blood cell distribution width and iron deficiency anemia among pregnant Sudanese women. Diagn Pathol. 2012;7:168.

[16] WHO. GUIDELINE DAILY IRON. Geneva: WHO; 2016.

[17] Zuffo CRK, Osório MM, Taconeli CA, Schmidt ST, da Silva BHC, Almeida CCB. Prevalence and risk factors of anemia in children. J Pediatr (Rio J). 2016;92(4):353-6o.

[18] Sabrina CM, Serudji J. Artikel Penelitian Gambaran Anemia Pada Kehamilan Di Bagian Obstetri Dan Ginekolog RSUP Dr . M . Djamil Padang Periode 1 Januari 2012. J Kesehat Andalas. 2012;6(1):142-6.

\section{PROFIL PENULIS UTAMA}

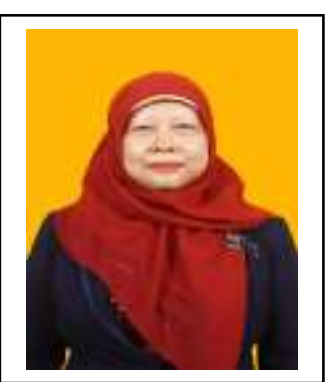

Sri Wahtini, merupakan dosen Kebidanan Universitas 'Aisyiyah Yogyakarta lulusan S2 IImu Hukum Kesehatan Universitas Kriten Semarang. 